\title{
Field performance of bio-primed seeds to suppress Colletotrichum truncatum causing damping-off and seedling stand of soybean.
}

\begin{abstract}
The soybean is prone to be attacked by Colletotrichum truncatum at seed and seedling stages, resulting in pre- and post-emergence damping-off. The efficacy of bio-priming for the control of damping-off of soybean caused by $\mathrm{C}$. truncatum and the final seedling stand using two fungal biocontrol agents (BCAs) Trichoderma harzianum and T. virens and one bacterial BCA Pseudomonas aeruginosa was evaluated under field conditions. Treatments consisted of chemo-primed with Benlate ${ }^{\circledR}$ as a positive control; bio-primed with P. aeruginosa; bioprimed with $\mathrm{T}$. harzianum; bio-primed with $\mathrm{T}$. virens; bio-primed with the mixture of $\mathrm{T}$. virens and $\mathrm{T}$. harzianum and the controls as hydro-primed and non-primed seeds. Trichoderma isolates used singly or as a mixture established on the seed surface with germinating hyphae, whereas the strain $\mathrm{P}$. aeruginosa colonized profusely as determined by increased colony forming units (CFU) from $1.2 \times 109$ to $5.1 \times 109$ seed- 1 after $12 \mathrm{~h}$ of biopriming. All bio-priming treatments significantly reduced pre- and post-emergence dampingoff relative to hydro- and non-primed seed controls. In general, bio-priming with $\mathrm{P}$. aeruginosa was the most effective treatment for controlling pre and post-emergence dampingoff, with reductions in disease incidence with increases ranging from $48.6 \%$ to $51.9 \%$ and $65.0 \%$ to $97.2 \%$, respectively. Moreover, P. aeruginosa resulted in enhancement of seed germination and healthy seedling stand ranging from $32.4 \%$ to $60.0 \%$ and $56.0 \%$ to $73.9 \%$, respectively. Bio-priming with $\mathrm{T}$. harzianum reduced pre- and post-emergence damping-off by $42.8-46.8 \%$ and $35.0-85.1 \%$, respectively. However, P. aeruginosa was generally comparable to $\mathrm{T}$. harzianum and the fungicide Benlate ${ }^{\circledR}$. The combination treatment of $\mathrm{T}$. harzianum and $\mathrm{T}$. virens produced compareable results to $\mathrm{T}$. harzianum alone, and $\mathrm{T}$. virens was the least effective of the bio-primed treatments. Bio-priming with P. aeruginosa or T. harzianum offered an effective biological seed treatment system and an alternative to the fungicide Benlate ${ }^{\circledR}$ for control of damping-off of soybean caused by $C$. truncatum of soybean.
\end{abstract}

Keyword: Biocontrol agents; Soybean; Bio-priming; Seed borne infection; Colletotrichum truncatum; Pseudomonas aeruginosa; Benlate. 